\title{
LEUKOCYTE PROFILE IN SOWS DURING LACTATION PERIOD
}

\author{
M. Joksimović-Todorović ${ }^{1}$, V. Davidović ${ }^{1}$, Lj. Bokan ${ }^{2}$ \\ ${ }^{1}$ Faculty of Agriculture, 11080, Belgrade-Zemun, Republic of Serbia \\ ${ }^{2}$ Clinical-Hospital Centre Zemun, 11080, Belgrade-Zemun, Republic of Serbia \\ Corresponding author: miratodo@agrif.bg.ac.rs \\ Original scientific paper
}

Abstract: During prepartum and postpartum period, there occurs in sows a significant change in the values of haematologic and biochemical parameters. The objective of this research paper was to examine the change in the count of the cells of white blood line in the course of lactation period. The trial was conducted on ten Swedish Landrace breed sows, having the blood taken on the first day postpartum (1-6h), and in the third and fourth week of lactation. The results obtained for haemotologic analyses have suggested the increase in total number of leukocytes and neutrophilic granulocytes, and the decrease in the number of lymphocytes, monocytes and eosinophils on the first day postpartum. In the third and fourth week of lactation a statistically significant fall in the number of leukocytes and granulocytes in relation to the first day was observed, along with a significant increase in limphocytes, monocytes and eosinophils. In examined time intervals the number of basophils did not change significantly. The neutrophil-limphocyte index was highest on the first day postpartum, while in the third and fourth week it was significantly lower.

Key words: sows, cells of white blood line

\section{Introduction}

In the course of lactation the sow augments its body reserves in order to provide production of milk. The anabolic processes postpartum are being converted into catabolic processes giving the priority to mammary gland over other tissue, so that the period of early lactation is followed by negative energy balance (Algers and Uvnäs-Moberg, 2007). Late pregnancy, parturition and postpartum period are followed by significant changes in biochemical and haematological parameters (Jain, 1993). However, sows very soon adapt themselves to the changes of these important parameters by means of different physiological mechanisms. In the course of lactation period the level of glucose in plasma is very low especially in the third and fourth week, while the level of urea is high due to immense utilization 
of proteins. A significant mobilisation of fats results in the increase in unsaturated fatty acids (NEFA) especially at the end of lactation period (Hulten et al., 1993).

Lactation is followed by a metabolic stress (Azab i Abdel-Maksound, 1999). Biochemical and haematological changes have been established in farm animals: dairy cows (Quiroz-Rocha et al., 2009), sheep (Vihan and Rai, 1987), sows (Dhabhar and McEven, 2001). Number of leukocytes is significantly increased during gestation and parturition in many farm animals, while in sows it is the highest on the thirtieth and sixtieth day of gestation in comparison with the ninetieth day. On the day of parturition (1-6h postpartum) the neutrophilia and lymphopenia were observed in sows (Jain, 1993).

The function and number of leukocytes varies in different reproductive phases, being initiated by changes in the concentration of some hormones (Österlundh et al., 2002). The steroid hormones (corticosteroids) play the most important role being in interaction with certain immunological functions. The relationship between endocrine and immunological system enables sows to resist infections postpartum. Besides hormonal status, genetics also influences the immunological characteristics in sows implying that by selection it is possible to obtain animals resistent to ailments characteristic for reproductive period (Vaiman et al., 1998).

\section{Materials and Methods}

The trial was conducted on ten sows of the Swedish Landrace breed at a pig farm in Serbia. Blood samples were taken after morning meal, from auricular vein and put into test tubes VF-053, on the first day postpartum (1-6h), and in the third and fourth week of lactation. The values of haematological parameters: total count of leukocytes, neutrophil granulocytes, limphocytes, monocytes, eosinophilic and basophilic granulocytes were determined by means of automatic haematologic analyser Arcus Diatron ${ }^{\circledR} \mathrm{Gmbh}$ Wien Austria. Neutrophil-limphocyte index was calculated by the means of following formula: $I=$ (number of neutrophilic granulocytes : number of limphocytes) x 100 .

The testing for the significance of differences obtained between mean values of haematological parameters was performed by Student t- test.

\section{Results and Discussion}

In the Table 1 the results obtained in the research on the amount of cells of white blood line in Swedish Landrace sows during lactation period (1-6h postpartum, third and fourth week of lactation) are shown. 
Table 1. Amount of cells of white blood line in Swedish Landrace sows during lactation period

\begin{tabular}{|c|c|c|c|c|c|c|}
\hline \multirow{2}{*}{ Hematological parameters } & \multicolumn{2}{|c|}{$\begin{array}{c}1-6 \mathrm{~h} \\
\text { postpartum }\end{array}$} & \multicolumn{2}{c|}{$\begin{array}{c}\text { Third week of } \\
\text { lactation }\end{array}$} & \multicolumn{2}{c|}{$\begin{array}{c}\text { Fourth week of } \\
\text { lactation }\end{array}$} \\
\cline { 2 - 8 } & $\bar{x}$ & $\mathrm{SD}$ & $\bar{x}$ & $\mathrm{SD}$ & $\bar{x}$ & $\mathrm{SD}$ \\
\hline Total count of leukocyte $\left(10^{9} / \mathrm{L}\right)$ & 18,80 & 1,62 & 15,79 & 1,49 & 13,63 & 2,10 \\
\hline Number of neutrophilic granulocytes $\left(10^{9} / \mathrm{L}\right)$ & 10,59 & 1,79 & 6,79 & 1,00 & 4,93 & 2,04 \\
\hline Number of lymphocytes $\left(10^{9} / \mathrm{L}\right)$ & 6,31 & 0,22 & 7,14 & 0,88 & 7,30 & 0,69 \\
\hline Number of monocytes $\left(10^{9} / \mathrm{L}\right)$ & 1,51 & 0,22 & 1,21 & 0,22 & 0,80 & 0,59 \\
\hline Number of eosinophils $\left(10^{9} / \mathrm{L}\right)$ & 0,19 & 0,09 & 0,47 & 0,23 & 0,49 & 0,22 \\
\hline Number of basophils $\left(10^{9} / \mathrm{L}\right)$ & 0,23 & 0,20 & 0,17 & 0,05 & 0,11 & 0,11 \\
\hline Neutrophil / lymphocyte index & 167,75 & 22,19 & 95,90 & 17,75 & 68,88 & 20,43 \\
\hline
\end{tabular}

From the results displayed in Table 1 it can be seen that the highest mean value in total number of leukocytes was recorded in sows immediately postpartum, $18,80 \pm 1,62 \times 10^{9} / \mathrm{L}$ blood. These values were significantly higher in relation to the values recorded in the third $(\mathrm{P}<0.01)$ and in the fourth week of lactation $(\mathrm{P}<0.001)$.

Number of neutrophilic granulocytes was highest also on the first day postpartum, and the lowest in the fourth week of trial. Between the values established on the first day and in the third week, and the first day and fourth week, a statistically highly significant differences $(\mathrm{P}<0.001)$ were established, while between the third and fourth week the determined difference was less significant $(\mathrm{P}<0.05)$. A mean number of lymphocytes was lowest on the first day $\left(6,31 \pm 0,22 \times 10^{9} / \mathrm{L}\right.$ blood $)$, and the highest in the fourth week $\left(7,30 \pm 0,69 \times 10^{9} / \mathrm{L}\right.$ blood). Statistically significant differences in the number of lymphocytes in trial animals were determined on the first day in relation to the next two blood takings at the level of significance of $\mathrm{P}<0.05$, while between the values in the number of lymphocytes in the third and fourth week there was no significant difference established.

The greatest mean number of monocytes in sows was determined on the first day postpartum, and the lowest in the fourth week. Only between the values obtained in the third week in relation to the fourth week no significant differences were determined. Number of eosinophils was the lowest on the first day, and the highest in the fourth week. Statistically significant differences were determined between the values obtained on the first day in relation to third and fourth week $(\mathrm{P}<0.01)$. Mean values in the number of basophils in sow blood were not significantly different in any of the examined periods. The highest neutrophillymphocyte index was recorded postpartum $(167,75 \pm 22,19)$. This value is significantly higher in relation to the values determined in the third and fourth week $(\mathrm{P}<0.001)$. A significant difference $(\mathrm{P}<0.05)$ between the mean values of this parameter in the third week $(95,90 \pm 17,75)$ and in the fourth week $(68,88 \pm 20,43)$ postpartum was established. 
The results of our research comply with the results obtained in the research of Jain (1993) and Damgaard et al. (2009) who stated that the lymphopenia and neutrophilia are the consequences of the increase in the level of corticosteroids in the first 24h postpartum. Damgaard et al. (2009) determined that the total number of leukocytes and neutrophil granulocytes was being increased postpartum, while the number of lymphocytes was low, wherein the value of neutrophil-limphocyte index was the highest on the first day of parturition. Also, Thorn (2000) determined that the total number of leukocytes was being decreased during gestation, while immediately postpartum there occurred neutrophilia and lymphopenia, wherein the neutrophil-limphocyte index had the highest value. Dhabhar and McEven (2001) established that leukocytosis, neutrophilia and lymphopenia were the consequences of sows sensitivity to stress. Decreased number of lymphocytes on the first day postpartum in relation to the prepartum and postpartum periods could be caused by a depression of estradiol as well (Magnusson and Einarsson, 1990).

\title{
Conclusion
}

Endocrine system in sows influences certain haematological parameters especially in the parturition period. Due to stress, concentration of corticosteroids increases what is manifested by leukocytosis and neutrophilia. In this way the organism prepares itself for the defence against certain infectious diseases often occurring in the first days postpartum.

\section{Acknowledgment}

This research paper was financed by the means of the project of the Ministry of Science and Technological Development of Serbia, TR 20110: Development and implementation of standards of welfare and biosecutiry aiming to improve technology of cattle and pig production

\section{Leukocitarni profil u krmača tokom laktacionog perioda}

\author{
M. Joksimović-Todorović, V. Davidović, Lj. Bokan
}

\section{Rezime}

Za vreme prepartalnog i postpartalnog perioda, kod krmača dolazi do značajnih promena vrednosti hematoloških i biohemijskih parametara. Cilj ovoga rada je bio da se ispitaju promene broja ćelija bele krvne loze u toku laktacionog 
perioda. Ogled je izveden na deset krmača rase Švedski Landras, od kojih je uzimana krv, prvog dana po partusu (1-6 h), treće i četvrte nedelje laktacije. Dobijeni rezultati hematoloških analiza ukazali su na povećanje ukupnog broja leukocita i neutrofilnih granulocita, a smanjenje broja limfocita, monocita i eozinofila prvog dana po partusu. Treće i četvrte nedelje laktacije, doslo je do statistički značajnog pada broja leukocita i granulocita u odnosu na prvi dan, a značajnog porasta limfocita, monocita i eozinofila. $U$ ispitivanim vremenskim intervalima broj bazofila se nije značajno menjao. Neutrofilno-limfocitni indeks je bio najviši prvog dana po partusu, a treće i četvrte nedelje značajno niži.

\section{References}

ALGERS B., UVNÄS-MOBERG K. (2007): Maternal behaviour in pigs. Hormons and Behaviour, 52, 78-85.

AZAB M.E., ABDEL-MAKSOUD H.A. (1999): Changes in some hematological and biochemical parameters during prepartum and postpartum periods in female Baladi goats. Small Ruminant Research, 34, 77-85.

DAMGAARD B.M., MALMKVIST J., PEDERSEN L.J., JENSEN K.H., THODBERG K., JØRGENSEN E., JUUL-MADSEN H.R. (2009): The effects of floor heating on body temperature, water consumption, stress response and immune competence around parturition in loose-housed sows. Res. Vet. Sci., 86, 1, 136145.

DHABHAR F.S., McEVEN B.S. (2001): Bidirectional effects of stress and glucocorticoid hormones on immune function: possible explanations for paradoxical observations. In: Adler, R., Felten, D.L., Cohen, N. (Eds.), Psychoneuroimmunology, third ed. Academic Press, 301-338.

HULTEN F., NEIL M., EINARSSON S., HAKANSSON J. (1993): Energy metabolism during late gestation and lactation in multiparous sows in relation to backfat thickness and interval from weaning to first oestrus. Acta Vet. Scand., 34, 9-20.

JAIN N.C. (1993): Essentials of Veterinary Hematology, Comparative Hematology of Common Domestic Animals. Lea and Febiger, Philadelphia, PA, 44-46.

MAGNUSSON U., EINARSSON S. (1990): Effects of exogenous oestradiol on the number and functional capacity of circulating mononuclear and polymorphonuclear leucocytes in the sow. Vet. Immun. and Immunopath., 25, 235247.

THORN C.E. (2000): Chapter 168: Normal Hematology of the Pig in Feldman FB et al.: Fifth edition Schalm's Veterinary Hematology, Copyright (C) 2000 Lippincott Williams \& Wilkins, 1089-1095.

VAIMAN M., CHARDON P., ROTHSCHILD M.F (1998): Porcine major histocompatibility complex. Rev. Sci. Tech. Off. Int. Epiz., 17, 95-107. 
VIHAN V.S., RAI P. (1987): Certain hematological and biochemical attributes during pregnancy, parturition and post-parturition periods in sheep and goats. Ind. J. Anim. Sci., 57, 11, 1200-1204.

QUIROZ-ROCHA G.F., LEBLANC S.J., DUFIELD T.F., WOOD D., LESLIE K.E., JACOBS R.M. (2009): Reference limits for biochemical and hematological analytes of dairy cows one week before and one week after parturition. Can. Vet. J., 50, 4, 383-388.

ÖSTERLUNDH I., HULTÉN F., JOHANNISSON A., MAGNUSSON U. (2002): Sows intramammarily inoculated with Escherichia coli at parturition: I Functional capacity of granulocytes in sows affected or non-affected by clinical mastitis. Vet.Immun. and Immunopath., 90, 35-44.

Received 3 May 2010; accepted for publication 14 June 2010 